УДК 82: 09: 821.161.2-2 “185/191”

Новиков А. О., доктор філологічних наук, професор, завідувач кафедри української мови, літератури та методики навчання

Глухівського національного педагогічного університету імені Олександра Довженка

\title{
«...ВІН ВВАЖАВ СЕБЕ ДВОРЯНИНОМ»: з історії роду Марка Кропивницького
}

Стаття присвячена вивченню генеалогічного дерева М. Кропивницького. Доводиться, що родовід драматурга бере свій початок з кіния XIV - початку XV cm. Прямі його предки мешкали на Поділлі. Це був заможний шляхетний рід. Первинне прізвище прашурів письменника Судимонтовичі, а пізніше вони згадуються як Судимонтовичі-Кропивницькі. Друга частина прізвища утворилася від назви села Кропивна, яким володіли родичіпопередники мития. Акиентується на тому, що історія з підтвердженням дворянського статусу М. Кропивницького знайшла відображення в його творчості.

Ключові слова: герб Сас, родовід М. Кропивницького, иляхетний рід, Поділля, Кропивна, драматургічна творчість.

The study of M. Kropyvnytskyi genealogy tree is under consideration in the paper. It is proved that the family line of the playwright originates from the end of the XIV $V^{\text {th }}$ - the beginning of the $X V^{\text {th }}$ century. His direct ancestors lived in Podillia (the southwestern part of Ukraine). It was a wealthy noble family. The original surname of writer's ancestors is Sudymontovych, and later their surname is mentioned as Sudymontovych-Kropyvnytskyi. The second part of the surname was formed from the name of the village Kropyvna that was owned by the writer's predecessor relatives. It is emphasized that the history concerning the confirmation of M. Kropyvnytskyi noble status was reflected in his works. 
Key words: coat of arms of Sas, M. Kropyvnytskyi family line, noble family, Podillia, Kropyvna, dramaturgical works.

Статья посвячена изучению генеалогического древа М. Кропивницкого. Доказывается, что родословная драматурга берет свое начало с XIV-XV веков. Прямые его предки жили на Подолье. Это был богатый дворянський род. Первичная фрамилия предков писателя. Судымовтовичи, а позже они упоминаются как Судымонтовичи-Кропивниикие. Вторая часть фамилии образовалась от названия села Кропивна, которым владели родственники-предшественники драматурга. Акцентируется на том, что история с подтверждение дворянского статуса М. Кропивниикого нашла отражение в его творчестве.

Ключевые слова: герб Сас, родославная М. Кропивницкого, дворянский род, Подолье, Кропивна, драматургичесикое, творчество.

Родовід Марка Кропивницького своїм корінням сягає у глибину століть. Його пращури були спадковими дворянами i належали до найчисельнішого в Галичині (Червоній Русі) шляхетного гербу Сас (Драг). Походження гербу до кінця не з'ясоване. За однією із версій, рід Cac (DRAG - SAS) в XI столітті започаткували графи Грифичі, землі яких знаходились у межиріччі Одри і Лаби. Ймовірно, цей рід входив до одного з племен західних слов'ян, яке під тиском германських феодалів переселилось у Трансільванію, точніше Мармарошу (частина теперішнього Закарпаття).

Українська історія гербу Сас, розпочинається з 1236 року, коли воєвода Мармарошу Гуйд переходить на службу очільника Галицько-Волинської держави князя Данила Галицького - пізніше короля Русі. Саме в цю добу саси починають розселятися по Галичині й Центральній Україні.

Чимало згадок про герб Сас міститься у фундаментальній праці М. Грушевського «Історія України-Русі». Вчений досліджує, зокрема, «Гербові групи західноукраїнської шляхти» [Грушевський 1995:610]. Серед низки інших згадується й рід Кропивницьких. Хоча останній, судячи з аналізу авторитетних історичних документів, уперше заявляє про себе на Поділлі, притому приблизно в цю ж добу - наприкінці XIV століття.

Будувати генеалогічне дерево роду Кропивницьких розпочав у 60-70-х роках минулого XX століття син драматурга Володимир. У Державному історичному архіві Ленінграда (тепер - Санкт-Петербург) йому вдалося розшукати «Справу про дворянство роду Кропивницьких», в якій зберігається чимало цінних відомостей про його пращурів. Пізніше цю роботу продовжив 
перший завідувач Меморіального музею М. Л. Кропивницького Віктор Ярош. Останньому в Житомирському обласному архіві пощастило натрапити на іншу не менш важливу добірку офіційних документів - «Справу Волинського дворянського депутатського зібрання про дворянство роду Кропивницьких». Свої напрацювання дослідник виклав у розвідці «Стежками завіяними (Родовід Марка Лукича Кропивницького)». Цінну інформацію про родичів-попередників Марка Кропивницького можна віднайти і на сторінках збірника ділових паперів доби перебування України у складі Речі Посполитої «Документи Брацлавського воєводства 1566-1606 років», опублікованого 2008 року у Львові.

Ці джерела дають право стверджувати, що родовід засновника театру корифеїв бере свій початок щонайменше 3 кінця XIV - початку XV століть i налічує понад десять поколінь. Практично всі прямі предки митця мешкали на теренах Центральної України (теперішні Вінницька і Кіровоградська області) й вірно служили українському народові. Первинне прізвище далеких письменникових пращурів Судимонтовичі, хоча пізніше вони частіше згадуються як Судимонтовичі-Кропивницькі, а в деяких офіційних документах кінця XVI - початку XVII ст. паралельно фігурують під прізвищем КайдашіКропивницьькі. Таким чином, повне їх прізвище було, очевидно, Судимонтовичі-Кайдаші-Кропивницькі. Щоправда, принаймні один iз предків драматурга увійшов в історію як Судимонтович-Шабан. Обумовлено це тим, що в ті далекі часи прізвища української шляхти не були сталими i пов’язувалися зазвичай із назвами маєтків, які перебували у іiї володінні, a оскільки власники маєтків час від часу змінювалися, змінювались і прізвища їхніх господарів. Однак поступово чимало прізвищ, що утворились у такий спосіб, закріпилися за своїми носіями і залишилися за ними навіть після того, коли ці садиби вони втратили. Така історія відбулась і з родом Кропивницьких.

У свій час Судимонтовичі-Кайдаші-Кропивницькі були, очевидно, досить заможним родом, який, проте, поступово збіднів. Принаймні у XVI - XVII ст. вони належали вже до середнього прошарку бояр-шляхти, який на території Великого князівства Литовського і Речі Посполитої називали зем’янами. 
Пращури засновника театру корифеїв володіли низкою маєтків. Серед них було й село Кропивна, розташоване на березі однойменної річки. Саме від назви цього села, власне, й утворилося їхнє прізвище. Знаходилося згадане село на території Брацлавського воєводства (теперішні Вінницька область без їі західної, північно-західної і північно-східної частин, частини Київської, Черкаської, Кіровоградської, Миколаївської й Одеської областей і Республіки Молдова). Цікаво, що про свої права на нього, а також деякі інші землі 3 лютого 1581 року під час виступу в польському сеймі у присутності короля Речі Посполитої Стефана Баторія заявив один із далеких предків драматурга брацлавський земський писар Северин Кропивницький. Він, зокрема, зазначив, що ці маєтності від Великого князя Литовського Вітовта отримав за вірну службу ще його прапрадід Григор Судимонтович, але відповідні підтверджуючі документи згоріли 8 жовтня 1580 року під час пожежі у Вінницькому замку.

В Україні наразі налічується кілька сіл із назвою Кропивна - У Вінницькій, Черкаській, Львівській та Хмельницькій областях. Останні дві 3 цього списку можна виключити відразу, оскільки жодна 3 їхніх частин не входила до Брацлавського воєводства (а саме там, за словами С. Кропивницького, знаходилися володіння його пращура). Щось подібне можна сказати і про село у Золотонському районі Черкаській області, хоча там $\epsilon$ навіть річка $з$ такою назвою.

До певної міри світло на цю проблему проливає старовинна грамота, яку віднайшов у Національному історичному архіві Білорусі Олександр Груша. Ця грамота датована 20 червня 1391 року і йдеться в ній про те, що дідич i господар Подільської землі князь Федір Коріатович дарує за вірну службу своєму слузі пану Гринькові землі «від верху Кропивни аж до устя Кропивни долов Буга» [Груша 2001].

Авторитетні історики переконані, що у грамоті Ф. Каріатовича йдеться саме про Кропивну, котра знаходиться у Хмільницькому районі Вінницької області [Петрук 2013:16]. До того ж річка Кропивна (що у Черкаській області) розташована в басейні Дніпра, тоді як пану Гринькові подаровані були землі в 
басейні Бугу. Особливої ваги цей аргумент набирає в контексті свідчення місцевих краєзнавців, що раніше тут була річка Кропив'янка (можливий варіант - Кропивна), яка пізніше змінила свою назву [Петрук 2013:17]. Неабияке значення має, звичайно ж, і час заснування сіл. Якщо вірити Вікіпедії, вінницька Кропивна вперше згадується ще 1200 року, тоді як черкаська лише у 1615 році, тобто через два з чвертю століття після описаних у грамоті подій.

Аналізуючи тексти грамоти Ф. Каріатовича й виступу на засіданні польського сейму брацлавського писаря, можна дійти висновку, що в обох документах, імовірно, йдеться про одну і ту ж особу - прапрадіда Северина Кропивницького Григора. Співпадають (чи майже співпадають) - імена (Григор - Гринько - Григорій), час видачі грамоти (доба Вітовта), назви топонімів і гідронімів (Кропивна), а також приблизне місце їх розташування (Брацлавське воєводство). Гринько, щоправда, отримав грамоту не від Вітовта, а тодішнього правителя Поділля князя Федора Коріатовича, але тут треба взяти до уваги ту обставину, що далекий предок Марка Кропивницького міг не пам’ятати таких деталей чи щось наплутати (можливо, навіть умисно). Адже сама грамота на той час була втрачена. Притому не виключено, що досить давно і навіть не ним самим, а кимось із його родичів-попередників. У такому разі пожежу у Вінницькому замку він, імовірно, використав як привід, аби заявити про свої претензії на втрачені землі.

Але, хоч якби там було, важливе значення має передусім сам факт існування цього Гринька (Григора - Григорія). Упродовж тривалого часу пан Гринько обіймав посади Червоногродського воєводи і Подольського старости. Вперше у зазначених статусах цей можливий далекий пращур Марка Кропивницького згадується в 1374 році [Молчановський 1885:221]. Володарі подільських земель досить часто змінювалися. 1395 року втратив свої володіння (принаймні частину) й пан Гринько. Тоді Великий князь Литовський Вітовт передав їх своєму двоюрідному брату князю Карибутовичу Дмитру Ольгердовичу. Але, на думку Олександра Груші, це не завадило Гринькові й надалі називатися «de Sokolecz» або «Соколецким». Щобільше, можливо, дещо 
пізніше Гринько (Григір) став іменуватися Судимонтовичем. Адже саме під таким прізвищем згадує свого прапрадіда Северин Кропивницький.

Однак, за великим рахунком, усе це лише гіпотези, котрі потребують подальшого підтвердження. Цілком доведеним можна вважати те, що першого відомого пращура Марка Кропивницького звали Григором (Григорієм) Судимонтовичем (перше покоління) i він був шляхетного походження. Щобільше, досить заможною і впливовою особою, оскільки за свою службу нагороджувався багатими маєтностями. Достеменно відомо, що роки його життя частково припали на добу Великого князя Литовського Вітовта (кінець XIV - початок XV ст.).

Григорів син - Іван Судимонтович-Шабан (друге покоління) - жив у часи Великого князя Литовського i короля Польщі Казимира Ягайловича (1447-1492 роки). Він теж, очевидно, був великим землевласником і належав до вищих кіл держави, позаяк, як і його батько, був щедро відзначений за свої заслуги - отримав у володіння від монарха «селище Монастирище у Білоцерківському старостві».

Важливо звернути увагу на те, що онук Григора, Олексій, носив уже прізвище Судимонтович-Кропивницький (третє покоління) й так само не залишився без монарших нагород. Олексію король Сигізмунд I (правив із 1506 по 1548 рік) дав привілей «на пасіку і Попівську поляну, котра лежить між землями міста Вінниці» [ДБВ 2008:275].

Досить цінні відомості в «Документах Брацлавського воєводства» можна віднайти i про деяких інших пращурів Марка Кропивницького. До таких важливих паперів належить, зокрема, офіційний лист (від 4 травня 1579 року) Микити Кайдаша-Кропивницького, яким він сповіщає про те, що продав свою частину маєтку Комарове Юрію Горецькому. У цьому листі він побіжно згадує свого брата Стефана, батька Григорія, дядька Івана, а також сина останнього Северина [ДБВ 2008:247-251]. Таким чином, можна дійти висновку, що в Олексія Судимонтовича-Кропивницького було два сини - Іван і Григорій (четверте покоління). 
Іванів син - брацлавський земський писар Северин СудимонтовичКропивницький (n'яте покоління) - був призначений на цю посаду згідно 3 указом короля Польщі і Великого князя Литовського Стефана Баторія 27 серпня 1579 року («Привілей короля Стефана Северинові Кропивницькому на брацлавське писарство») [ДБВ 2008:243]. На початку 80-х років XVI століття «у складі почту брацлавського воєводи» [ДБВ 2008:299] він брав участь у війні Речі Посполитої з Московією - під Полоцьком, Великими Луками, Торопцем і Псковом. Помер Северин, очевидно, на початку 1589 року, оскільки саме тоді в ділових паперах згадується вже як небіжчик [ДБВ 2008:22]. Прикметно, що маєтки Велике Комарове й Мале Комарове спочатку були успадковані його двоюрідним братом - «королівським дворянином Стефаном» [ДБВ 2008:453]. А 12 липня 1605 року, тобто через 16 років потому, очевидно, вже після смерті Стефана, права на спадщину заявили Северинові сини - Олександр, Михайло й Іван.

Михайло Северинович Судимонтович-Кропивницькйй (mосте покоління) народився приблизно наприкінці 1570 - початку 1580-х років (його батько помер 1589 року), а період його активної діяльності припав на першу половину XVII століття. Значну частину свого життя він мешкав у Вінниці, оскільки упродовж кількох десятиліть працював в управлінському апараті Брацлавського воєводства, адміністративний центр якого 1598 року перемістився саме в це місто. У 1616-1640 роки Михайло Кропивницький обіймав посаду підсудка, тобто помічника земського судді. Окрім того, він із 1613 по 1635 рік в якості одного 3 двох послів (у сучасному розумінні сенаторів) представляв Брацлавське воєводство в сеймі Речі Посполитої. Висловлював йому таку високу довіру брацлавський сеймик (аналог місцевої ради), притому не менше п'яти разів упродовж двадцяти двох років. I недарма, оскільки брацлавський делегат активно відстоював у вищому представництві країни інтереси своїх виборців, тобто православних вірян, права яких після укладення в 1569 році Люблінської унії були знехтувані польською владою. 
Неабиякі заслуги мав цей пращур Марка Кропивницького і перед вінницькою громадою. Він, зокрема, активно сприяв заснуванню у рідному краї монастирів східного обряду, допомагав одновірцям матеріально. Наприклад, 1635 року із власних заощаджень виділив кошти для міської парафіï св. Марії, завдяки чому були придбані значні земельні угіддя й засновано жіночий монастир Благовіщення (тепер - жіночий монастир Святої Трійці у Браїліві). Остання згадка про Михайла Кропивницького як брацлавського підсудка припадає на 1640 рік. Ім'я цієї неординарної особистості увічнено в одній із вінницьких вулиць.

Подальші відомості про рід Марка Кропивницького відносяться вже до другої половини XVIII ст. Відтак у генеалогічній таблиці митця $є$ певна прогалина. У «Справі Волинського дворянського депутатського зібрання...» представлений «духовний заповіт, вчинений 20 квітня 1768 року Василем Кропивницьким», про розподіл коштів поміж його синами Олександром i Яковом та рідним братом Григорісм [Ярош 1990:202]. Ні Василь, ні його брат, ясна річ, не могли бути синами Михайла Кропивницького, який відійшов у вічність, очевидно, ще у першій половині XVII ст.

Про синів Григорія - Василя, Федора й Івана - міститься згадка у посвідченні, виданому овруцьким предводителем дворянства 4 жовтня 1805 року. Відомо, що Іван мав чотирьох синів - Якова, Йосипа, Степана й Івана [Ярош 1990:202]. Останній і є дідом Марка Кропивницького, про якого він залишив спогади у своїй «Автобіографії (За 65 років)».

Прикметно, що у XVIII ст. вже не згадуються попередні прізвища пращурів Марка Кропивницького - Судимонтовичі й Кайдаші. А документи, які засвідчували дворянський статус його роду, в якомусь із поколінь начебто були втрачені. Хоча, швидше за все, глибинна причина цієї проблеми має політичне підгрунтя, суть якої полягає в тому, що після приєднання Поділля до Російської імперії наприкінці XVIII ст., царський уряд не всю українську шляхту автоматично зрівняв у правах із російськими аристократами. Від багатьох старовинних родів, що століттями мешкали в цьому краї, царські чиновники 
вимагали додаткових підтверджень їхньої приналежності до привілейованого стану. Передусім це стосувалося тих, хто брав участь у збройних повстаннях проти російської експансії. Доброю ілюстрацією до цього $\epsilon$ історія 3 дворянством Тобілевичів. Очевидно, таку ж чашу змушений був випити до дна й рід Кропивницьких.

Клопотання про відновлення статусу-кво розпочав батько Марка Кропивницького Лука Іванович. Останній 1835 року зробив відповідне подання на ім'я царя, обгрунтовуючи своє прохання тим, що дворянами вважалися його рідні дядьки Яків і Степан. У листопаді 1842 року надійшло повідомлення 3 Київської центральної ревізійної комісії, в якому зазначалося, що паперів, котрі надіслав Лука Кропивницький, недостатньо для представлення справи для розгляду у Департаменті Герольдії.

Естафету у Луки Івановича перейняв його син. У своєму посланні до сенату від 29 квітня 1904 року він зазначав, що спочатку його батько, а потім уже й він сам надсилав різні довідки та виписки до Волинського депутатського зібрання, однак звідти кожного разу традиційно надходили повідомлення про те, що не вистачає якихось важливих паперів. Коли ж задовольнялися ці вимоги, висувалися нові. 10 жовтня 1905 року із сенату надійшов нарешті указ за № 2829, в якому повідомлялося, що справі про підтвердження дворянства не можна дати руху до тих пір, поки документи про володіння пращурами Кропивницького нерухомим майном не будуть завірені в Київському центральному архіві. Але оскільки цього зробити не можна «до завершення слідства про підлоги, виявлені в актових книгах изього архіву» [Ярош 1990:201], сенат не може задовольнити клопотання прохача [Ярош 1990:202].

Після сенатського вердикту Кропивницький більше не переймався вирішенням цієї практично безнадійної справи. За словами драматургового сина Володимира, його батько «ніколи не намагався демократизувати своє походження». Щобільше, без дворянського титулу митець незрідка відчував себе «і з г о с м у суспільстві [...] Маркові Лукичу часто доводилося стикатися й клопотатися $з$ найрізноманітніших питань, насамперед пов'язаних 3 
театром [...] Чиновники, починаючи від якого-небудь пристава і до генералгубернатора, дивилися зверхньо на людину, в якої на візитній картщі не було ні звання, ні чину. Тільки виключна популярність Марка Лукича і загальна повага, якої він зажив, допомагали йому долати перешкоди» [Кропивницький 1968:53].

Своїми клопотаннями про приналежність до дворянського стану Кропивницький до певної міри повторив долю Карпа Тобілевича - батька братів Тобілевичів. Останнього імперська влада змусила в офіційних документах іменуватися міщанином, «доказывающим дворянство», що стало сенсом майже всього його життя. Цей епізод із біографії Карпа Адамовича знайшов, як відомо, відлуння в комедії його сина Івана Карпенка-Карого «Мартин Боруля».

Прикметно, що після завершення своєї «дворянської епопеї» Кропивницький, як зазначає його син, при нагоді навіть не проти був покепкувати зі свого «аристократизму». Щобільше, згодом це знайшло відображення у його п’єсі «Хоч $з$ мосту в воду головою» (1909), де переноситься на український грунт дія 3 комедії французького драматурга Жана-Батиста Мольєра «Жорж Данден, або Обдурений чоловік». Згаданий твір $\epsilon$ сатирою на українських багатіїв із середовища сільської буржуазії, які в гонитві за дворянськими титулами прагнуть узяти шлюб із доньками аристократів, але незрідка опиняються в комічній ситуації. Таким $\epsilon$ центральний персонаж п’єси багатий селянин Харько Мандрика. Одружившись із дочкою збіднілого дворянина Кочержинського, він досить скоро усвідомлює, що жорстоко помилився («дворяне рідняться не 3 нами, а 3 нашими грішми») [Кропивницький 1959:563]. Нові родичі постійно докоряють Харькові за його мужицьке походження, а жінка-аристократка (Зізі), яку віддали заміж усупереч iii бажанню, майже відкрито зраджує нелюбу-чоловіку з гульвісою-сусідом. Допомагає Харьковій дружині в походеньках спритна покоївка Лукерка, яка, до речі, нагадує дотепних наймитів 3 іншого твору Кропивницького - веселої комедії-оперетки «Пошились у дурні» (1875). 
Акцентуючи на снобізмі нових родичів головного героя п’єси, Кропивницький наділяє їх родовими прізвищами - Мурчак-Бурчак-СтирчакКочержинський і Грище-Прище-Трище-Хомутинська. Останнє - явний натяк на власний «аристократизм» автора твору, оскільки, за словами його сина, письменнику нібито хтось сказав, що його пращури носили подвійне прізвище Грище-Кропивницьких.

Генеалогічна таблиця роду Марка Кропивницького, а надто історія, пов’язана 3 намаганням підтвердити його дворянський статус, суттєво розширюють уявлення про походження письменника. Все це дає змогу краще зрозуміти світогляд майстра, глибинну сутність його творчості.

\section{БІБЛІОГРАФІЯ}

Груша 2001 - Груша Аляксандр. Невядомая грамата Фёдара Карыятавіча 1391 г. // Беларускі Гістарычны Агляд. [Електронний ресурс]. - Режим доступу : http://www.belhistory.eu/alyaksandr-grusha-nevyadomaya-gramata-fyodara-karyyata vicha-1391-g.

Грушевський 1995 - Грушевський М. Історія України-Русі : в 11 т., 12 кн. - К. : Наук. думка, 1991. - Т.6. - 1995. - 680 с.

ДБВ 2008 - Документи Брацлавського воєводства 1566 - 1606 років. Львів: Наукове товариство імені Шевченка, 2008. - 1219 с.

Кропивницький 1968 - Кропивницький В. М. Із сімейної хроніки Марка Кропивницького : (Спогади про батька) / Мистецтво, 1968. - 214 с.

Кропивницький 1959 - Кропивницький М. Твори в 6-ти т. - К. : Держлітвидав УРСР, 1959. - Т. 5. - 631 с.

Молчановський 1885 - Молчановський Н. Очерк известий о Подольской земле до 1434 года. - Киев, типография императорского університета св. Владимира, 1885. - 434.

Петрук 2013 - Петрук В. Любіть Україну (автобіографічна повість життя, кохання і науки). - Вінниця, 2013. - 272 с. 
Ярош 1990 - Ярош В. Стежками завіяними (Родовід Марка Лукича Кропивницького) / Віктор Ярош // Спогади рол Марка Кропивницького : Збірник. - К. : Мистецтво, 1990. - 216 с. 